\title{
АНАЛИЗ ПРЕИМУЩЕСТВ ИНТЕГРАЦИИ ДЛЯ ИРАНА И ЕАЭС *
}

\author{
(c) 2020 Бурцева К.Ю. \\ кандидат экономических наук, доцент Департамента учета, анализа и аудита \\ Финансовый университет при Правительстве Российской Федерации, Россия, Москва \\ E-mail: aksentiya@mail.ru
}

Ключевыми целями Евразийского экономического союза являются расширение сотрудничества и повышение экономической конкурентоспособности государств-членов, а также содействие стабильному развитию в целях повышения уровня их жизни. В настоящее время Иран и ЕАЭС стремятся к интеграции и существенному увеличению товарооборота. В статье проанализированы преимущества интеграции для Ирана и ЕАЭС. Предложена классификация стейкхолдеров, заинтересованных \незаинтересованных в развитии интеграционных процессов между Ираном и ЕАЭС, выделены преимущества и риски заинтересованных сторон.

Ключевые слова: ЕАЭС, Иран, интеграция, многостороннее партнерство, анализ, преимущества, риски.

Евразийский экономический союз - международный экономический союз, включающий страны, расположенные в центральной и северной Азии и восточной Европе. Государстваучредители - Беларусь, Казахстан и Россия учредили союз договором, вступившим в силу 1 января 2015 года. Блок был создан отчасти в ответ на экономическое и политическое влияние Евросоюза и других западных стран. 17 мая 2018 года в Астане обе стороны подписали трехлетнее временное соглашение о вступлении Ирана в ЕАЭС, которое начало действовать с 27 октября 2019 г.

Государства-члены этого союза имеют обширные торговые связи друг с другом. Стоит отметить, что Россия, как крупная региональная страна, имеет около 500 миллиардов долларов товарооборота с миром и несопоставима с Беларусью и Арменией. С образованием этого экономического союза государства-члены ищут экономические и инвестиционные обмены. Экономические обмены с государствами-членами Союза могут помочь Ирану повысить свою экономику.

Явным преимуществом является при взаимной торговле прозрачная и предсказуемая среда. Помимо самих снижений импортных пошлин, временное соглашение предусматривает соблюдение основополагающих принципов международной торговли его участниками. В нем прописана схема, которая аналогична регламенту ВТО, она накладывает на Иран требования и обязательства несмотря на то, что партнеры не являются членами ВТО. Также стороны достигли договоренности, которая обязывает их не применять необоснованные нетарифные меры, которые ограничивают торговлю в отношении товаров, перечисленных в соглашении. Конечно, необходимым является то, чтобы развивать торговлю всеми товарами, потому что в среднесрочной перспективе это также будет служить критерием, подсказывающим, какие товары станут объектом либерализации на следующем этапе.

Иран обладает потенциалом для экспорта товаров на новый рынок. Новые рынки помогут иранским заводам и иранскому частному сектору восстановить свое финансовое положение, поскольку их финансовое состояние испортилось из-за санкций, введенных США. В краткосрочной перспективе Иран может удерживать потенциал экспорта таких товаров, как пищевая продукция, фрукты, сухофрукты, стройматериалы, а также электронное и механическое оборудование в Евразийский экономический союз. Соглашение предоставляет Ирану значительные возможности в области торговли продуктами питания, химическими и строительными материалами, экспорта инженерных услуг и ряда других сфер.

\footnotetext{
* Статья подготовлена по результатам исследований, выполненных за счет бюджетных средств по государственному заданию Финуниверситету
} 
Иран и ЕАЭС перечислили в своем временном соглашении 862 вида сырьевых товаров, на основании которых Иран будет пользоваться упрощенными условиями экспорта и более низкими таможенными пошлинами по 502 товарам, и то же самое касается 360 товаров из стран - членов ЕАЭС. Из 862 пунктов, упомянутых в соглашении, 639 - промышленные товары, а остальные 223 - сельскохозяйственные товары. Торговое соглашение между Ираном и ЕАЭС может увеличить стоимость внешней торговли Ирана на \$10-15 млрд. за три года.

Цена и качество иранских товаров станут главным вопросом. Товарам Ирана следует стремиться быть конкурентоспособными по сравнению с товарами других стран, чтобы занять большую долю на новом рынке. Новый рынок обладает потенциалом для частного сектора Ирана и позволит государству в целом восстановить свои производственные мощности, а также качество производства.

Население стран, входящих в ЕАЭС, вместе составляет более 180 миллионов человек, с площадью 20 миллионов квадратных км, ВВП этих стран составляет более четырех триллионов долларов в год. Эти показатели определяют стабильность экономического сотрудничества Ирана с другими странами Союза. В условиях санкций, введенных США, ЕАЭС дает возможность Ирану нарастить отношения с соседями и сохранить мир и стабильность в регионе.

Иран планирует использовать собственную валюту вместо использования доллара, как это уже происходит во взаимоотношениях с Россией. Они стараются использовать собственные валюты - риал и рубль. До России и Ирана Китай пытался использовать в своих деловых отношениях с другими странами собственную валюту - юань, стараясь снизить тенденцию использования доллара в экономических отношениях с любой страной в любой части мира. Использование национальной валюты дает возможность Ирану и России пытаться увеличить объем своей торговли.

Рассмотрим преимущества ЕАЭС, связанные с развитием интеграционных процессов с Ираном. Снижение пошлин на некоторые экспортные товары позволит ЕАЭС получить максимальную выгоду от торговли с Ираном. Основные экспортируемые Ираном в Евразийский блок товары включали яблоки, сжиженный природный газ, фисташки, киви, огурцы, соленые огурцы, изюм и апельсины.

По временному соглашению ЕАЭС получает таможенные преференции (снижение тарифных барьеров на 20\% - 75\%) по таким товарным группам как мясная и масложировая продукции, отдельные виды кондитерских изделий и шоколада, а также металлы, косметика, отдельные виды электронного и механического оборудования. Иранская сторона получает таможенные преференции (снижение тарифных барьеров на $25 \%-100 \%)$ по очень широкому списку товарных групп, в первую очередь по овощам, фруктам, сухофруктам, строительным материалам и изделиям из цветных металлов [1].

По промышленным товарам средний уровень ставок ввозных пошлин Ирана снизится с $22,4 \%$ до 15,4\%, то есть на 7 п.п., Союза - с 8\% до 4,7\%, то есть на 3,3 п.п. По сельскохозяйственным товарам Иран уменьшит пошлины в среднем с $32,2 \%$ до 13,2\%, то есть на 19 п.п., Союза с 9,6\% до 4,6\%, то есть на 5 п.п. [2]

Сотрудничество с Ираном поможет странам ЕАЭС укреплять сотрудничество в проекте коридора Север-Юг, именно благодаря Ирану может быть создан обширный совместный экономический мост из Лиссабона в Персидский залив.

Подписание меморандума между Россией и Казахстаном - ключевыми поставщиками пшеницы на мировой рынок - и Ираном станет первым шагом к возрождению полных цепочек поставок высококачественной пшеницы из ЕАЭС в Иран и весь регион. Сотрудничество с иранскими партнерами весьма перспективно, пшеница из России и Казахстана будет поставляться в Иран без таможенных пошлин и иных эквивалентных ей сборов.

Кроме того, Иран разрешит транзит пшеницы через свою территорию и поддержит ввоз пшеницы в рамках реализации своповых контрактов. Он также обеспечит, чтобы существующие или будущие запреты, а также другие ограничения на использование, сбыт, продажу, поставку и продажу пшеницы Ирану не распространялись на пшеницу, временно ввозимую на иранскую территорию для дальнейшей переработки и экспорта.

Казахстан готов обеспечить эффективную логистику поставок товаров из Ирана на рынок ЕАЭС и из Союза в Иран, так как в первом квартале 2018 года наблюдалась положительная динамика товарооборота между Казахстаном и Ираном, то есть рост объемов торговли до всту- 
пления соглашения в силу составил 72\% [3].

В качестве основных стимулов для развития армяно-иранских торговых отношений армянское руководство рассматривало строительство третьей высоковольтной линии электропередачи между Ираном и Арменией, а также автодороги Север-Юг, Мегрийской гидроэлектростанции и Мегрийской свободной экономической зоны. Но эти проекты застопорились в последние годы по экономическим и внутриполитическим причинам.

В отчете о девятимесячной торговле Ирана и ЕАЭС указывается, что среди стран-членов ЕАЭС наибольший рост товарооборота Ирана пришелся на соседнюю Армению, так как экспорт страны в Армению за указанный период вырос на $169 \%$, а импорт из соседней страны-на $49 \%$.

Обе стороны применяют тарифные скидки, предлагаемые на основании соглашения, и никаких проблем в этом плане не возникло. Раньше Турция доминировала на армянском рынке, но сейчас иранская продукция намного дешевле турецкой, что дало Ирану конкурентное преимущество [4].

Плодотворные последствия соглашения также значительны в торговле Ирана с другим соседом-Россией, к концу текущего иранского календарного года (19 марта 2020 года) объем торговли между двумя соседями достигает почти около 2-х миллиардов долларов, что будет на 17,5 процента выше показателя предыдущего года [4].

Несмотря на то, что зона свободной торговли облегчила торговлю Ирана с государствамичленами ЕАЭС, следует учитывать, что это ограниченное соглашение действует в течение трех лет, поэтому трейдеры должны максимально использовать нынешнее состояние.

Хотя временное соглашение планируется привести к полнофункциональному соглашению между ЕАЭС и Ираном, так как министр торговли Евразийской экономической комиссии заявил, что временное соглашение между Ираном и ЕАЭС может быть превращено в постоянное уже через три года. Временное соглашение создало хорошую возможность для Ирана расширить свое присутствие на региональных рынках, и если страна достигнет постоянного соглашения с Союзом, то сможет закрепиться в Евразийском регионе.

Постоянное соглашение может открыть но- вую главу не только для торгового статуса Ирана, но и для его транзитной роли в регионе, поэтому при создании необходимой инфраструктуры страна должна признавать требования и требования евразийских целевых рынков для их удовлетворения.

Также можно отметить и взаимную торговлю между Белоруссией и Ираном, которая довольно динамично развивается с 1993 года. В 2017 году взаимный товарооборот между Беларусью и Ираном вырос втрое. Очень положительная динамика наблюдалась и в первом квартале 2018 года. Наряду с традиционным торгово-экономическим сотрудничеством развивается инвестиционное сотрудничество. Беларусь инвестирует в машиностроение Ирана [5].

Анализ преимуществ интеграции для Ирана и ЕАЭС предложено провести на основе применения концепции стейкхолдеров (заинтересованных сторон) в развитии интеграционных процессов между ее участниками. Основные заинтересованные стороны были классифицированы на внешних и внутренних. Среди внутренних выделены непосредственные участники соглашения, имеющие прямую заинтересованность в интеграции: Иран и ЕАЭС. Для них выделены преимущества развития процессов сотрудничества в рамках экономического союза, а также потенциальные риски. Внешние стейкхолдеры были определены исходя из реальных рисков, возникающих для них в результате активизации интеграционных процессов ЕАЭС, и их возможностей препятствовать данным процессам. Предложенная классификация стейкхолдеров, заинтересованных в развитии интеграционных процессов между Ираном и ЕАЭС представлена на рисунке 1, также выделены преимущества, возможности и риски стейкхолдеров.

В заключении следует отметить, что торговое соглашение с Евразийским экономическим союзом предоставляет иранским государственным и частным фирмам большие возможности для расширения бизнеса и торговли, вступление в этот союз открывает ворота очень крупного рынка, дает стране прекрасные возможности внешней интеграции. В экономической точке Иран может увеличить объем торговли с государствами-членами и попытаться экспортировать больше товаров в члены ЕАЭС и импортировать товары из этих стран. 


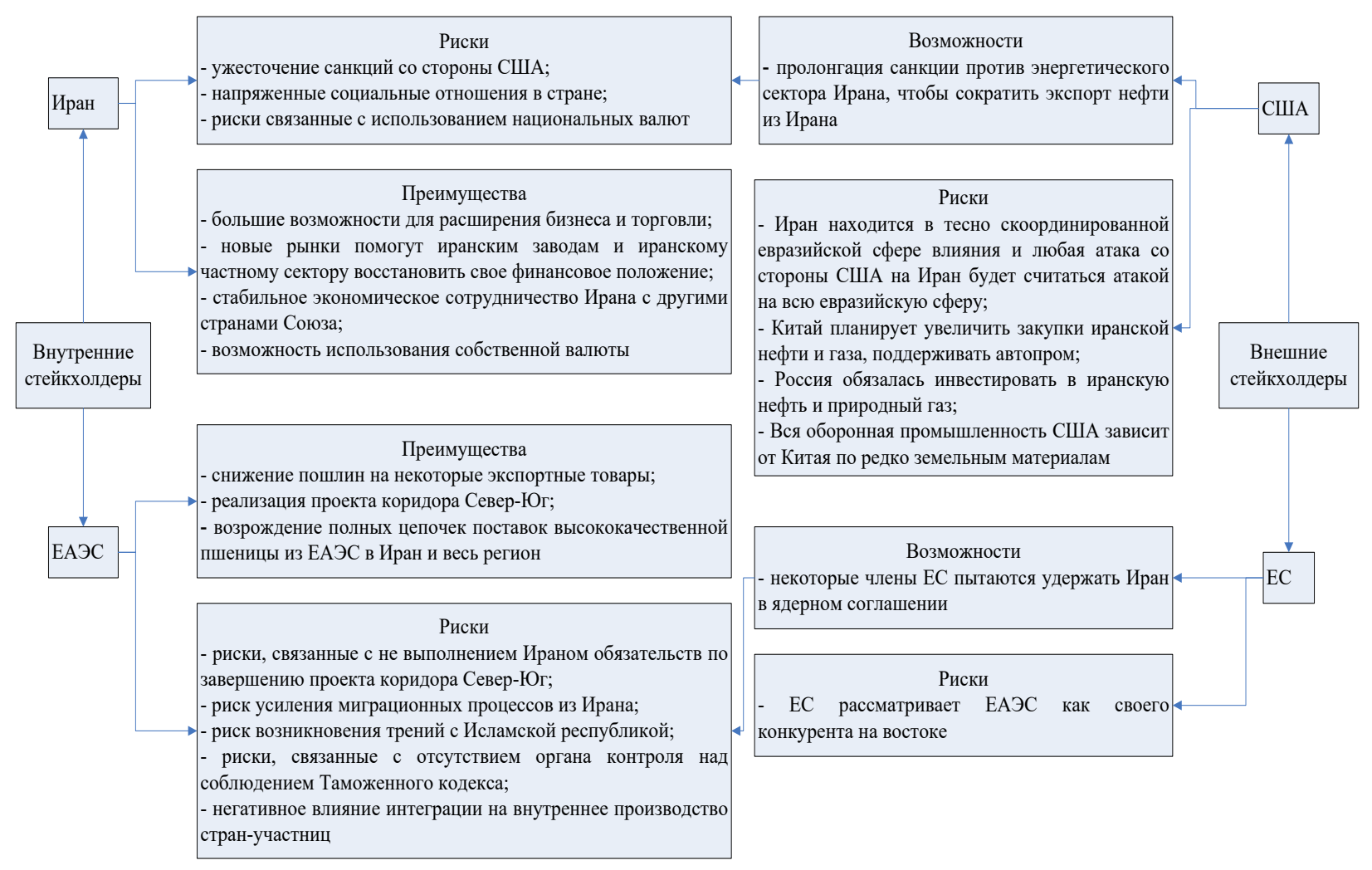

Рисунок 1. Предложенная классификация стейкхолдеров, заинтересованных/незаинтересованных в развитии интеграционных процессов между Ираном и ЕАЭС с выделением преимуществ и рисков.

\section{Библиографический список}

1. Евразийская Экономическая Комиссия. Interim Agreement leading to formation of a free trade area between the Eurasian Economic Union and its Member States, of the one part, and the Islamic Republic of Iran, of the other part 2018. URL: http://www.eurasiancommission.org/ru/act/trade/dotp/sogl_torg/Documents/Interim\%20 Agreement\%20EAEU-Iran_final.pdf Дата обращения: 18.04.2020 г.

2. Подписано Временное соглашение, ведущее к образованию зоны свободной торговли между ЕАЭС и Ираном [Электронный ресурс].// Евразийская Экономическая Комиссия: [сайт]. [2018]. - Режим доступа: http:// www.eurasiancommission.org/ru/nae/news/Pages/17-05-2018-1.aspx. Дата обращения: 20.04.2020 г.

3. Аскар Мамин: «Казахстан готов стать логистическим мостом между Ираном и ЕАЭС»... URL: https://kursiv. kz/news/politika/2018-05/askar-mamin-kazakhstan-gotov-stat-logisticheskim-mostom-mezhdu-iranom-i-eaes Дата обращения: 20.04.2020 г.

4. Первые успехи торгового соглашения Ирана с ЕАЭС URL: https://www.iran.ru/news/economics/114974/ Pervye_uspehi_torgovogo_soglasheniya_Irana_s_EAES Дата обращения: 20.04.2020 г.

5. Подписано Временное соглашение, ведущее к образованию зоны свободной торговли между ЕАЭС и Ираном URL: http://www.eurasiancommission.org/ru/nae/news/Pages/17-05-2018-1.aspх Дата обращения: 30.04.2020 г. 